\title{
QUO VADIS MUSIC EDUCATION? SKETCHING A PHILOSOPHY FOR MUSIC EDUCATION
}

\section{SUMMARY}

Introduction. Art and skill subjects are being pulled down in the Finnish elementary school education as well as on the classroom teacher education level. The importance of subjects like reading writing and math is being proclaimed all the time. In this article we focus on music education in Finnish school as well as in the music school institutes.

The Aim of the Study. To find new solutions in music education's philosophical and psychological basis and raise discussion about the philosophic questions as well as discussion about the importance of good music education on general level.

Materials and Methods. The materials on which examination is based are curricula of music schools and institutions and different educational theories. The method of the study is examining existing situation and philosophical basis of Finnish music education and considering the many sides of it.

Results. We try to find solutions in the problems by proposing new ideas and models in music education.

Conclusions. More research is needed to show the problems in field of music education and to help solving them in the way which leads to educate and foster not only good musicians but also happy and satisfied people.

Key words: music education at school, music schools and institutions, philosophy of music education

\section{INTRODUCTION}

The art and skill subjects as well as artistic expression itself not only in Finnish school but also in other institutions are descending into the role of a stepchild as they are forced to live in the shade of the subjects like math and science which are regarded as more important ones. Also in classroom teacher education the resources of these subjects have been driven down at every turn since the 1990's. In the public school debate the significance of math and science has constantly been put out thanks to the wonderful success in PISA-research for Finland. Still, the same PISA research showed clearly that the Finnish school children are not happy at school today. They enjoy less being at school compared to other countries. International research also clearly shows that the school motivation descends during the first school years at the same time as the motivation changes from internal to external motivation (trying to get good marks). This happens in connection with the increasing school exhaustion (Gottfried et al., 2001; Salmela-Aro et al., 2007).

The purpose of this study is to open the eyes of decision makers about the situation which has led the Finnish music school system in current crises where young people are willing to learn instrument playing but not in the way they are taught in music schools and institutes today. Also the 
music theory and ear training teaching are in big trouble today. The curriculum in music schools has come to a point where it has to be rebuilt in a modern way.

\section{AIM OF THE STUDY}

To find new solutions in music education's philosophical and psychological basis and raise discussion about the philosophic questions as well as discussion about the importance of good music education on general level.

\section{MATERIALS AND METHODS}

The study is based on examination of current music school's curriculum in light of different educational theories. The method is critical analyze and connecting current situation into psychological and educational theories trying to find new solutions into existing problems.

\section{Background}

Already J. Dewey (Dewey, 1916/2008) in his times supported the harmonizing curriculum where the art and skill subjects were balanced with the others. He stood up for them as the USA struggled in the deep depression in the beginning of the 1930's. In the current Finnish comprehensive school system we cannot see a sign of such a balance. It looks like the decision-makers do not understand the great significance of the expression subjects (Art and skill subjects) as means of creativity, cooperation and emotional education which creates and builds a bridge to finding one's own humanity in growing processes. Unfortunately, the art and skill subjects still today are seen as some kind of lightening and indispensable entertainment in the squeezing of the earnest school routines and efficacy salience.

The reasons for this may also be looked after inside art and skill subjects themselves: the teachers have not been able to make their voice heard loud. Art and skill subjects have also been taught focusing only theory and performance centrality like the other subjects mentioned. The lack of research in art and skill subjects also has showed in teaching the art and skill subjects' same contents in the traditional way from year to year. The problems show in the fact that art and skill subjects are in the tag end when we speak about liking the school subjects. According to T. Regelski (Regelski, 1996, 25-27) people find their way to art experiences because they offer emotional and affective enjoyment. Also the curriculum of Finnish comprehensive school aims in arising lifelong learning in all areas (OPS, 2004). This can be achieved through the art and skill subjects as they generate internal enjoyment for the pupils. Because the school working in these subjects is active work basing on doing, making and practising, they offer lots of possibilities for experiencing success together with the feelings of self-control, possession and efficacy. All this is possible also to those pupils who do not success in other, traditional school subjects like math, science or foreign languages. Art and skill subjects create emotions of effectuation through feelings of mastery, control, efficacy and competence. The activities which are in use in art and skill subjects are also common for school beginners already from kindergarten and home: it is spontaneous drawing, singing, moving, playing and pottering.

When we know the high level of music as a hobby among the schoolchildren we can say that if music is not liked as a school subject the problem is in "serving" the subject. One of the reasons for this is that the school as an institute has never understood nor supported or promoted the culture of the young people, on the contrary the school has always seen it as a contender for the set of values which the school represents. This has gone so far that in 1970-1980's a specific form of music was developed for only school music educational use. This music had no connections to real life or any real music style or genre. It only was played at school with the school music 
instruments outside the surrounding musical world or music cultures.

First of all music is the art of extremely strong emotional feelings, this is where the school is not at its best. Professor Matti Koskenniemi found out in his research project of didactical process analyzes in 1970's that the school does not support emotional expression. This result concerned as well positive and negative emotions, which were seen as disturbing factors in the emotionally neutral (or should we say emotionally poor) and information centred school's learning atmosphere. Instead of totally rejecting emotional expression, the school should essentially focus on developing the emotional life and emotional education, which is attainable through the art and skill subjects, especially music education. At this very moment the emotional education is integrated in health education - a solution, which we do not see as very wise. Art and skill subjects include naturally intrinsic therapeutic co operational achievement, which is conveniently promotes mental well being at school. This helps in balancing the overdosing of the information centred package of knowledge, which is pushed into heads of pupils ever since the beginning of the school. This is one of the consequences of the needs and requirements of the modern society. Meaningful experiences form the essence of teaching and learning the art and skill subjects and this means that affective and emotional elements are always present - elements which are most important in emotional education.

The problems in human life are not consequences of the lack of knowledge or information; they are consequences of problems in emotional life where the development of emotional life has somehow been disturbed. Anxiety and depression, the new national diseases in Finland cannot find a proper outlet channel because of the performance centred society, which causes the feelings of insufficiency and alienation from the real life. It is not a wonder that the markets of the different medication for depression, affective syndrome and sleeping problems have widened in last few decades massively. Schools have their own special mission in preventing mental problems and in this mission the art and skill subjects are in key position. The intrinsic operational connection in art and skill subjects between the affects, emotions and expressing them make it possible to easily achieve feelings of safety, confidence and togetherness in group and society way better than in any other school subjects. Art and skill subjects do not need or require language skills or completion because activities and doing things come first before thoughts. This way they offer an excellent route for expression to those who do not have words to articulate their emotions and feelings. Cooperation also is an essential element in these subjects, which give great possibilities for achieving many-sided cooperative creative productions. Researchers of wellbeing at school often highlight the emotional contents when they speculate the school enjoyment. This means the level of enjoyment in the everyday achievements at school and the significance of them in proportion to pupils' own needs, attitudes and emotional condition (Kannas et al., 1995, 131).

Herman Hesse (Hesse, 1972) tells in his book "Glass-pearl game" about a utopia society Kastalia, which is dedicated to science and arts and where citizens play a mystical conceptional game through which it is possible to learn complex skills but also to create new ideas. The background of the glass pearl game has to do with the social reality, which was shaken by the barbaric Nazi powers which Hesse tried to counterbalance through describing a creative and culture appreciable ideal society. Although the author does not say it directly his game means actually music, through which opens possibilities not only to learn creative inventing but also many other skills of life. Through music a human being learns collaboration, listening to others, improvising, arrangement, accompaniment and playing solos which all effect in social skills in connection with every kind of 
emotional and cognitive growth.

S. Paavola (Paavola, 2006) examined in his dissertation the processes of invention basing on the conception "abduction" by Peirce. "Abductive" reasoning is in connection to many kinds of cognitive processes like emotions, instincts, perception and in general all achievement concerning signs and operational action. Music includes a lot of creative abduction where inventing and refining new solutions forms a knowledge creating metaphor, which has a transfer effect in many non-musical sectors of life. The decision makers should notice that "music is not only music" but dealing with it offers the keys to the logics of creative invention. Music forms a miniature world, a micro cosmos in which the innovation, expression and achievements are connected to real life, which according to Alfred Einstein may be described: behind the music there we may sense a glimmer of some other, deeper reality. Similarly Eino Kaila (Kaila, 1954) says that there is structural similarity, which he calls isomorphic between music and profundity (See Tarasti, 2003).

\section{Outlining the philosophy of music education}

Educational philosophy is as old as the human race itself, but music education philosophy has not interested the researchers until lately. Therefore we outline our own ideas of music education philosophy as a start for the discussion.

Music education is like a tripod, the three feet being music, society and education. The allegory is suitable, because it will fall if any of the feet is missing. If the education does not deeply concentrate in the essence of music, music culture or the status in society or the needs and interests of an individual, it will not be reasonable.

Musicians or music educators do not necessarily contemplate on the essence of music. They usually take it as given. Sometimes the essence of music is stiffened in frivolous definitions of which the probably most famous and still sometimes used is "music is sound which is organized by man" (Varése; see Clayson, 1973). Music is like an amoeba, which may be defined in many ways and from many starting points strongly depending in the aims of the definer. Therefore the definitions the researchers make show more the focus of the definer himself.

Music can be described through Ludwig Wittgenstein's (Wittgenstein, 2001) semantics of "possible worlds". Music is a possible world, which takes and gets different forms from different perspectives or points of views. A teacher experiences music through his own background and education differently compared to pupils he is teaching. A cultivated symphony music lover goes through different emotional affects in Mozart's music than a rock musician or rock music fan. V. Rantala (Rantala, 1986) explores music through language philosophy perspective. He accentuates music as "the language of possible worlds". The syntax of the language of music, the note writing, gives unrestricted possibilities to create, build and reconstruct different "imaginable worlds". Creating new music means defining matters of time and space in which the deepest idea is to mediate the significances and meanings of the results of the creative process which rises from the mental-bodily states, experiences, memories and mental impressions of the creator, the composer (See Lehtonen, 1986; 1988).

Correspondingly the reception of music is premised on the psychic motion which becomes activated through hearing the music, which tunes the listener's internal processes which are directly linked in emotional life giving the meaning and significance to the whole musical experience. In this way of thinking listening to music also is an active process because it is based on continuing interaction between the heard music and listener's psychic activity. In music we hear something, 
which resonates in meanings in our emotions which music again interacts. Listening to music means the floating of dynamic psychic contents backwards and forwards through our mind.

Our conception is that music originally is a process inside a human mind, which is seeking an outlet through the essence of music, which can be heard (Leichter, 1984). We also can talk about musical thinking, which gets the external essence in music when it is playing. The essence of music and the phenomena itself may be compared to the relationship between thinking and speaking. The musical thinking needs the external achievement as slightly as thinking requires speaking (Lehtonen, 1996; Mansnerus, 1992; 1993). When we hear music playing it actually means outsourcing the "internal processes" of the music creator and this makes it possible to share them with others, the listeners. The same principle can be added in all artistic expression where the artist is processing the pictures and shapes inside his head to become impressive and spectacular pieces of art.

A musician or a composer outlets the internal processes (memories, conceptions, feelings, emotions, associations) transforming them to the dynamics of the forms which move through sounding and which at the same time has emotional response in the listener. During the process the dynamic changes in music start internal processes in the listener, which resonate with his memories, conceptions and experiences. The musical experience starts and maintains psychic operational processes. It forms a vital chain of interaction, which includes reciprocal internalising and outsourcing. Music cannot be canonised because musical expressions continuously seek their own paths as if they were under spontaneous evolution pressure. Music is renovating a possibility for a human mind, which because of its anthropomorphic essence awakens the world of emotions, imagination and fantasy even for those, whose internal reality has been seriously disturbed or damaged. Music is able to express all spaces, processes and forms of reality. Still, it never commits to "real categories", because there is nothing healthy or diseased in it although these may occur in the emotional processes of a listener.

Existentialist M. Heidegger (Heidegger, 1995) writes that music is one possible way of constructing or constituting the world, a way to deal with the world somehow. The world not only does exist but it is constructed only through dealing with it, through making something out of it, because the world is organized through the general action which is guiding our activity at the very moment. Both L. Wittgenstein (Wittgenstein, 2001) and M. Heidegger (Heidegger, 1964) were interested about the way the "the world of being" and the "significance of the world" are constructed or on the other hand how the significance and meanings are built and constructed inside the language. Both answer to the question by referring to the essence of activity (Lehtonen, 1988). In this way music forms a wonderful way of telling about one's own thoughts and taking part in building and constructing the whole world. It is not possible to overestimate the importance of the society-critical rock music in 1960's as the contributor of the great social change. It influenced strongly for example the solving of the racial problems, ending the war in Vietnam and in general social atmosphere in USA.

Music is an artefact, which simultaneously addresses our whole personality reaching at the same time both conscious and unconscious sides in it. Musical experiences have clear equivalency to the world, which for example is touched when a psychoanalyst is examining the irritating and pleasure giving tasks (Rechardt, 1984). Music has been seen as an object where musicians and listeners place their emotions (Lehtonen, 1986; 1988; 2007; Winnicott, 1966; 1971; 1959/1982). On the other hand, music rather forms a series of continuing interaction than a solid object. This 
makes all the speech about music insufficient and in adequate full of exterior musical cultural structures. The deepest essence of music is escaping from our reach of words and this is why we may ask with the words of Wittgenstein: is music one of those matters, which cannot be discussed and should be quiet about. The deepest essence of music is different matter than music education and music culture which always carry strong external musical valuation charges, targets and ambitions intrinsically. At their best these get only a little closer to the true essence of music.

According to a new research by Lehtonen (Lehtonen, 2009) music often works as an "existential hiding place" - a potential space - where every kind of playing is possible and allowed (Winnicott, 1966). A potential place can be described also using I. Nonaka and H. Takeuchi's (Nonaka, Takeuchi, 1995) conception " $b a$ ". Intensive listening to music and music making and playing bring strong flow experiences in which the every day anxiety eases for a moment to be replaced with dynamic flowing of our own imagination (Csikszenmihalyi, 1997). The "intrinsic essence of music" is connected in the archaic significance levels which according to development psychological research (Stern, 1995) closely remind the interaction between a mother and a child which alike the music includes continuously moving shapes under tension and relief. This kind of vital affects are the basic forms of being alive, the same which musical experiences represent also later. At early developmental stage the senses of a child have not completely become differentiated and that is why between them there is lot of correspondences, which Stern (Stern, 1995) calls amodal sensing. This ability does not disappear later and it is possible to gain conceptions, images and other experiences through music.

The Lehtonen's (Lehtonen, 2009) research focused on top level musicians' significant musical experiences and showed (as one of the main results) the meaning of the music as a "personal space", a state of mind where enjoyment and satisfaction can be reached in the middle of the storms of the world outside. Also the universal significance of music is in connection with controlling of the pressures, threats, and anxiety and finally finding the psychic peace of mind. Simplifying a little we may say that the essential meaning of music is to find psychic balance of mind. Cultural anthropologist Paul Willis (Willis, 1978) research, Profane Culture, which focuses on two different juvenile cultures connects music in "seeking one's internal self" and in identification to a collective set of values represented by music. According to Willis the pressure coming from outside world forces young people turn more and more in their own intrinsic world.

Also J. Torvinen (Torvinen, 2007) sees music twofold, both as an expression and also as an output channel, which is especially typical for the technological modern world and its anxiety. He uses Martin Heidegger's (Heidegger, 1964) existential phenomenology by connecting individual's anxiety from fragmented society especially in the feelings of chaos and Insignificance where anxiety is seen both in the experiences of the individual and in the social confusion and structural violence. There also is substantially a strong "psychic commitment" in music (Lehtonen, 1993; 2007; Lång, 2005) which means that through dealing with music an individual can handle oppressive and chaotic contents of own mind. Music brings apart the difficult thoughts to a "symbolic distance" which smoothens and helps dealing with them as music and inside music.

The researchers have found out lately instead of peace of mind and psychic balance music studies and musical achievement often cause strong feelings of stress and anxiety. In our performance centred culture also music studying and musical performance are often connected to competition mentality, hard requirements, performance pressures and stress and feelings of insufficiency. The situation has offered a need for many kinds of performance coaching and 
stress controlling management enterprises, which aim to help performers reach the level of top achievement in their performances.

The whole music school and conservatorium institution is built on hierarchical "skill demonstrations and level rating situations". These situations often become artificial and unnatural with no connection at all to real-life musical performance situations because the only listeners in these tests are those who give the critic and do the rating of the skills. In this the music institutions need strong self-reflection. We may ask whether these external elements make the significance of music as a balancer of the psyche totally impossible.

One reason for the rejection of the emotional significance in music has been the supremacy and domination of music theory in the music institutions, which has meant an obvious point of view that understanding music demands the knowledge of a specialist and at the same time the comments of non-specialist are being silenced. While doing that the expressive, social and emotional effects of music have been pushed aside representing secondary importance creating an illusion that one can not know anything about music without having these mentioned analytictheoretic skills (McClary, 1985; Torvinen, 2007). This tradition has produced a great amount of analytic listeners (concert police) who keep looking for mistakes through only concentrating in details of the music.

At the same time group of critics miss the emotional effects of musical performance. Music as an every-man's right has been has been silenced through stamping the emotional effect of music irrational. It is a question of ideological-elitist domination through which the music has been provided only as a privilege for those able to read notification and who know music theory and analyzing. J. Torvinen (Torvinen, 2007) speaks about "dictatorship of experience" which, by highlighting one way of experiencing music puts the other ways of experience aside. It is not a wonder that there are lots of people who start music discussion by telling first that they do not understand music at all in Finland (see also Välimäki, 2005).

\section{On the essence of music education}

Education may be defined in many ways. We will not introduce them all but we will focus on comparing two different definitions. J. A. Hollo (Hollo, 1959) in his classical definition says that education is "bringing to grow" which means that the educator is obligated to conduct the learner as far as possible in each situation. According to J. A. Hollo (Hollo, 1959) the task of the educator is to clear the way from the barriers which might restrain the learning and growth, their task is to create a positive atmosphere for growing and learning at the same time also to strengthen the learner's own will, creativity and viability. After the conducting stage the learner (growing individual) moves into self-growth stage taking the ethic responsibility about the growing through reflecting himself/herself and the environment. Every individual must find his/her own relationship with music as it cannot be given ready by any outsider. In every human being there is an intrinsic ability to emotionally experience music which forms abase for making music and rehearsing playing music. The educator's task is to create positive environmental situations for musical abilities to occur and he should remove every kind of barriers which could restrain the development of them.

This humanistic definition is quite opposite of the behaviouristic definition which is close to technical education. Behaviouristic point of view means "regulating the environmental circumstances in purpose of reaching some aims". Behaviourists think that when they know the terminal behaviour it is possible to get to it through regulating the time used in learning and 
the environmental circumstances. These definitions focus on different matters, the first one is underlining the growing processes and the later one highlights the product most important.

J. A. Hollo's definition also emphasizes the profound dialogue, which should creatively proceed from occasion to another between the growing individual and the educator. The behaviourists for their part see the education mostly one-way interaction where the educator's task is through (symbolic) rewards and punishments to guide the growing individual toward the aim, which was earlier defined. He/she also should take care that the learner will not go to wrong paths during the process. The firs definition underlines a symmetric, understanding human relationship between the educator and the learner. According to the later - asymmetric - definition the educator acts as a controller who manipulates the learner and the environment of growth to react the goals.

The definition by J. A. Hollo presses the increasing of the growing consciousness, creativity and the significance of independent thinking. The other definition is based on growing materializing where learner's individual ambitions often are seen as a hindrance for reaching the goals. According to the first definition the educator is a fellow-man, friend and a mentor who gives advises and opens gates to new possibilities but at the same time leaves a lot of space and responsibility for the learner. In the behaviouristic thinking the educator is a censor who supervises, controls and criticizes the development of the learner. Now we may ask how these definitions could be in connection with the institutions and the world of practice, conventions and curricula of music education.

The idea of man in these two definitions is totally contradictory to each other. Hollo's idea of man is based on humanism with a human being seen as intentional, creative, implication building and independently thinking, history-owning individual who is formatted by environment but who also has aptitude and ability to change the environment himself/herself. The base of this definition lies on the tradition of the western philosophy, which has roots as long as classical philosophies.

The roots of behaviourism are in industrial revolution where this "revolution in learning" quickly produced decent workers for the assembly lines of the factories. The contents of teaching were split into "small atoms" which were then taught step by step from smallest to biggest and from easiest to most difficult ones. This way people effectively learned to work as "parts of machines" and they learned to manage in their tasks without making mistakes just by obeying the instructions. "Psyche" or "consciousness" does not belong in behaviourist's vocabulary because they deal with manipulating the behaviour. The roots of behaviourism are deep in history, they can be found from the legions of ancient Rome as well as Prussian army which both mass-produced powerfully and concordantly working war machine basing on effective and countless repeat of practise. Also in modern army the concept of mass-production is in use, which tells the quintessence of the whole thing.

Behaviourism has been criticized so widely that we do not repeat it. On the other hand, a great deal of the criticism has been left on the level of mere speech. According to speeches and proclamations the music education has been totally renewed although it is obvious that the iron-hard armour-plating of the behaviourism still are guiding the achievements holding both the Institutions and those who act there in its grip.

The speeches about reflectivity have not always become reality. On the contrary, the speeches about the change may only be a narcissistic trick, which aims in creating visions of being dynamic and this way it also rejects the critic. In the real world the master-journeyman type of 
teaching is rolling through the most of the field of instrument teaching.

\section{On the philosophy of music education}

Those philosophical starting points, which we earlier presented, are the ones which we have been lecturing the last two decades on the introduction courses for the students of education. It is surprising that these basic questions do not exist at all in the discourse about music education today. The reason for this distortion is that the Finnish music school institution is a closed system, which first selects the suitable and competent enough candidates and then assimilates them inside and as a part of the system. At the same time those who are inadaptable to the system are removed from disturbing the institutes operation.

Symbolically speaking the roadsides from the music schools are filled with dead bodies if we look at those who have stopped their musical hobby or studies in music schools or conservatoires. When people talk about well-functioning music school system it is like an essential optical illusion because those working with specially selected students will not necessarily ever get to think about the basic questions about the meaningfulness of the whole studying. According to the principle, "dogs bark but the caravan keeps a-going" the drop out phenomena and breaking up the studying can easily be blamed on students' lack of musical talent, laziness, lack of general gifts and lack of motivation. The greatest myth in these institutions is that the reasons behind the lack of meaningfulness rise from the students themselves.

Lately a lot of attention has been given to the Venezuelan music education system called "El Sistema" which has been getting glorious results working with poor children from slums. Their lives have found totally new paths after starting the classical music-playing hobby. Although the “Venezuelan wonder" reminds quite a lot former Soviet union's music education or East-Germany's "wonderful" achievements and results in athletics, El Sistema still includes remarkable pedagogical insights. The system gives unselected and by musical talent untested children a possibility to get proper music education through which they have found the harmonizing significance of music that works as a counterweight for the rough reality of the slums. The greatness in the idea lies exactly in the lack of selection and testing.

In Finland we should ask weather the music education in the compulsory school could work the same way so that therapeutically comprehending music education could offer a new possibility to those children and youngsters who are in danger of dropping out of society and who are never seen in music schools or conservatoires. El Sistema has been used in Finland as an argument for lifting up classical music because there have been seen only the good and life quality lifting effects of exactly the classical music although any kind of music would offer the same effects. Lots of youngsters in Finland have found a lifebelt for dropping outside society in band playing and rock music. There are many examples on this.

A well organized music education may also become a motivation for the whole school going. Sometimes the only positive experiences at school come from some art and skill subject where also those who are not good in theoretical subjects have a possibility to gain experiences of success. At their best the art and skill subjects may lead into a flow experience (Csikszentmihalyi, 1997), although, we unfortunately must notice, that at the same time these subjects at their worst may cause the cruellest humiliations. The experiences are the force, which makes these subjects stronger. The idea in them is to build new skill-knowledge on earlier experiences and to achieve possibilities for applications in authentic context (Bilimoria, Wheeler, 1995).

The greatest challenge in music pedagogy is to educate pupils who are not especially 
musically talented and who do not have former functional relationship with music. The most challenging music education work is done at the grass root level among the unselected pupils whose interest for music must first be awakened and after that the personal music relation must start to be built in cooperation with the teacher. This kind of thing never happens in a musicteaching institute which from the beginning selects the pupils through testing and which obeys curriculum where only the "best and suitable" may survive and follow through. The structure of the system makes sure that creative thinking is not needed and "the normal ways of achievement lead into normal results".

We profess that many music education institutes still are functioning and guided under severe behaviouristic principles: music education is strongly institution- and teacher-controlled; the contents of teaching have been split into partial performances of courses - "atoms" - the theory and practise have been separated from each other. In addition the students must give hierarchically proceeding tests which are estimated numerically and where the criteria of the terminal behaviour are strictly prescribed beforehand. The centre planned and lead system which determinates its own results becomes close to "mass production" aiming to product a critical mass of sufficiently talented among whom it aims to sift those who are good enough to become "stars". In the vocabulary of the army there are "educational inspections" where the success will improve the career development especially among the army instructors.

The system puts both the teachers as well as the students in the position of an object. The teacher must lead the students through the beforehand defined system of degrees and curricula with continuing testing of the intermediate goals. Putting people in the position of an object is invisible selection where the weakest soon notice that they are not important nor valuable because they are not reaching the goals, which are put by the system itself. The requirement for continuous proof of progress brings in the competition, which causes anxiety and stiffens creativity and growth.

Music education institutes follow the idea of "banking education" which was strongly criticized by Paolo Freire (Freire, 2000). Instead of inventing new innovative achievements it concentrates on storing the contents and customs, which maintain prevailing power structures. In music education the "banking education" is hiding in the curricula, lists of repertoires, estimation and pedagogical customs which maintain the traditional power-arrangements that have frozen in the course of time. The system has focused on conscientious storage of the values and traditions of the western classical music. The traditional music education is founded on an imitation culture where nearest possible copies are tried to be made of the reference models. Of course, this is only a part of the truth because for example a professional musician has to know and be able to perform the essential repertoire. Still we may ask does a culture, which mostly is based on plagiarism generate creativity. Similarly in visual arts education it would be copying great works of past masters as authentically as possible instead of producing creative and original artefacts as now is being done. Does the musical distinctiveness and creativity only belong to elite of the chosen few or on the other hand to those who operate outside the whole system.

P. Freire (Freire, 2000) also writes about the "culture of not opening one's mouth" which suppresses the dissenters by using either charges or punishments. This activity often is invisible as it is noticed only in situations where those who speak with critical tones of voice find themselves on the sidetrack, unemployed or not getting well-earned awards. "The culture of not opening one's mouth" does not see any problems because they are not talked about aloud. This lack of open and many voiced conversation leads into anxiety and alienation which is seen inside the institution so 
that the teachers do not enjoy being there or miss the meaningfulness of their work or carry it out in disinterested manner.

In "banking education" a student has to practise hard and take part in all activities, which are required without any kind of resistance. To succeed in the institution he must learn all the written and unwritten traditions, customs and regulations. The teachers are like "little technicians" (Giroux, 1988) who keep the wheels rolling by greasing the producing machinery. This is the way the "banking education" little by little eats the actor's human capital (see Becker, 1964), which leads into non-alignment, alienation and loosing the importance and meaning of the work.

In the field of music education we also can see the effects of "generis amnesia" the general loss of memory" highlighted by P. Bourdieu (Bourdieu, 1968, 1984, 1985). According to that the music education institute system is like an "ideal created by God" which may be described, "what has been before me will also be there after my time". Many of the actors in field of music education believe that critic and demands for change will jeopardize the glorious results produced by the current system and this way will lead into chaos. Those who have reached a good status and competence through the current system are hanging in the "banking education" as long as they can because the new ways of action create a danger for their professional competence. This may be the feeling of for example a piano lecturer who has played only written music from the notebooks for all his/her life and find free accompaniment and improvising totally strange, difficult and unfamiliar.

One reason for the "banking education" and "generis amnesia" is unfortunately that many of the teachers have not been sustaining and updating their professional competition. In music education we regrettably often come across the thought that the professional competence once gained will do for the rest of the life. This is despite the rapidly changing music culture with new learning environments create continuingly new qualification requirements which cause the need for lifelong regeneration. "Turtle defence" which merely sticks to old traditions and customs only leads to problems becoming critical.

The music education system is stiff also because the institutions and their curricula are ruled by a kind of zero-sum game where nothing can be added because nothing can be aborted. It is natural, that the teachers are hanging onto their lessons but the principle should not be leading the whole system - the tail may not shake the whole dog. It is very difficult for the current music school system to answer the needs of society because there are instruments lacking students and the others who have way too many candidates applying for teaching.

The voice of one individual is not strong enough to change the system. What would be strong enough to cause the beginning of real evolution in music school institution in Finland? We proclaim that the starting point of the unavoidable revolution lies on the inevitable and profound changes in both society and music culture, which in time will unstoppably crumble the basic structures of the system.

\section{RESULTS}

\section{Focus from the ivory tower to the grass root level}

The Finnish music education system is unique compared to any other country. This is because it has offered quality instrument teaching for the children living in all parts of the country. The underlining of the uniqueness and quality of the system has regardless lead into the situation where the decision makers have become sure that the music school institution would be able to take care of all music education of which the society is responsible. This has led into neglecting and 
failing in the field of compulsory school music education, which is showing as atrophy everywhere at schools. The music school system, which only is interested about finding talented pupils, does not highlight music as everyman's right, on the contrary it forms a hierarchic pyramid where the work of those on basic level is not appreciated at all.

All-round educational compulsory school music education has been a target of continuing reduction with the excuse that those talented who are interested in music have been able to try to get in the music schools and conservatoires to foster their love for music. In some cases this actually has become true. At this turning point the emotions are put aside and the traditional system starts concentrating to create the student's relationship to music as intellectual-analytical as possible basing on the specialist way of thinking. Instead of being a "cheap joy of sense organs" the student's relationship with music becomes an expert's relationship which only belongs to the chosen few. Unfortunately the ideals of this kind of expert's relationship have been the goal for many music teachers at compulsory school instead of pupil-originated teaching starting points.

Theoretic-analytic relationship with music means rejection where part of the significance of audible music is denied. A devoted expert tries to catch from the music the universals he/she has earlier assimilated and which guide his/her conceptions on how music should be performed and played. This is the reason the critics tend to tell the performers afterwards how the program should have been performed and what elements were poor and incorrect in it. This happens although the written text only poorly is able to describe the audible performance of music. Music education has, in addition to rejection of emotions, been stigmatized by anti-hedonism, which according to V. Jankélévitch (Jankélévitch, 2003) is one form of alienation, which focuses on the fear of the whole existence of the human being. He counterpoints that all "technical analyzing" is a way of avoiding the touch of "the fascinating magic of music" and it also means rejecting to fling oneself at the mercy of it.

All this is paradoxical because for example the curricula from the year 2004 lists a big amount of ambitious targets including musical identity, understanding the starting points of music cultures in different countries, unprejudiced relationship with music as well as the possibilities which music offer in creative and meaningful life (OPS, 2004). In the floating opportunism these goals are so wide that not even music professionals could be able to reach them. This kind of curriculum may be called poetry, which is like a barrel of utopian hopes keeping everything good and beautiful inside. If the resources of school music education in future will be kept in the current level, it will lead the teachers into big troubles. On the other hand, the text of the curriculum makes a good example of the fact that the words and practise are far, far away from each other.

\section{School music education around the world}

In different parts of the world music education has been organized in different ways. For example the Brazilian public schools do not offer music education at all. In private schools music is sometimes taught, though. Many other countries are still in the middle of building a music education curriculum, which would cover the whole country (China). In some other countries the part of art and skill subjects is even smaller than in Finland. Some countries (Mexico) have connected music education with drama. In many countries the teacher education does not have music at all, while in the Finnish system it still is hanging in spite of continuing diminishing. The main responsibility in Finnish system has been saddled to the students and their voluntary work in learning the instrument playing.

The Finnish compulsory school education has kept art and skill subjects in the curriculum 
although taking away lessons for some other more important subjects has continuously reduced them. All this has been done on children's expense. Art and skill subjects are in main focus when we speculate pupils' enjoyment and pedagogical well being at school. The research of well being has merely started and much more would be needed to show the importance of art and skill subjects at school well being point of view.

\section{CONCLUSIONS}

\section{Towards new models}

Because future elementary school classroom teachers are not offered a possibility to gain well enough skills to fulfil the goals of full-blooded music education, we should start to think about new solutions for the problem to make things better. One possibility might be linking the music school institutions directly with the compulsory school music education. Then in the best situation both systems could offer their best parts in use of the other. Still, the danger is that the stiff patterns and models of the music schools would implanted to the school as they are now and they would take the place of the all-round music education. That would be a catastrophe. This idea already has been tried and carried out. The city of Helsinki and the East-Helsinki music school made a cooperation agreement in 1999 about integrating the private music school with the compulsory elementary school system. The aim was that during the nine years of comprehensive school pupils would be offered a possibility to gain both compulsory school and music school certificate of the studies. In this model the school days were planned to be comprehensive and as one system of teaching without long waiting times between the lessons (http:/www.edu.fi/hankkeita/ musiikkiperuskoulu). The basic teaching is given by classroom teachers and the music education is given by the music schoolteachers offering instrument teaching, music theory and music history subjects. The instrument teaching is done in small groups and it is put inside the usual schoolwork. The school is called the Music oriented elementary school. This is a unique project in combining two different curricula together as the two institutions working under different legislation are cooperating. During the year 2007-2008 all nine-class grades will be within the system.

In this experiment the whole responsibility of the music education has been given to music schoolteachers. Their own education has traditionally focused on instrumental skills while the educational studies have almost totally been put in the background. The goals in this music oriented elementary school music education are the same as in the curricula for the basic curricula of art education in the free institutes. The music teaching in this experimental project concentrates strictly in classical music, because the East-Helsinki music school is focused on classical music only. One doctoral thesis is under work concerning this project.

\section{Developing the elementary school classroom teacher education}

The music education inside teacher education suffers from same problems as the elementary school: too little lessons in music. In all art and skill subjects the amount of lessons should be upraised in a vital way. This would be the only solution for improving the skill level of future classroom teachers in for example field of music so that they would be realistically able to reach the goals, which are set in curriculum. The courses in instrument skills in playing piano or guitar should be widened to a level where there would be time to really get to know the piano playing technique together with the proper selection of school songs. Nowadays, only one credit for 16 hours of teaching does not offer a possibility to reach that level in piano or guitar playing. For the reasons of profiling there is not even a possibility to choose art and skill subjects as specialization subjects in all teacher education universities. Still, we should keep in mind the pedagogically 
wonderful possibilities, which a good classroom teacher has to offer good music education, which would be much better than those of a subject teacher. This is because the subject teacher education focuses on the subject, music. This makes music teachers teach only music while they should be teaching the pupil as a classroom teacher does. This could easily be reached if the focus in curricula of teacher education would offer more lessons in use of the art and skill subjects in future.

\section{Reaching to future through research}

In many teacher education universities music education research is being done. Pretty seldom these researches use the methods of action research, which would make it possible to cooperate with the schoolteachers. The music subject teacher education in universities of Oulu and Jyväskylä as well as in Sibelius-Academy also product some research in music education. So far we have not seen many researches in Finland, which would directly offer help in changing the working patterns and formula in the school world. It seems that a new approach of music didactics would most urgently be needed in the Finnish music education.

\section{REFERENCES}

1. Bilimoria, D., Wheeler, J. (1995) Learning Centred Education: A Guide to Resources and Implementation. Journal of Management Education 19 (3), p. 409-428.

2. Becker, G. S. (1964) Human Capital. New York: Columbia University Press, p. 3-20.

3. Bourdieu, P. (1968) Outline of Sociological Theory of Art Perception. International Social Science Journal, No 4, p. 589-612.

4. Bourdieu, P. (1984) Distinction. A Social Critique of the Judgement of Taste. Cambridge Mass: Harward University Press, p. 9-18.

5. Bourdieu, P. (1985) Sosiologian kysymyksiä [Questions of Sociology]. Jyväskylä: Vastapaino, p. 45-64 (in Finnish).

6. Clayson, A. (1973) Edgard Varese. London: Sanctuary Publishing, p. 118-140.

7. Csikszentmihalyi, M. (1997) Creativity: Flow and the Psychology of Discovery and Invention. New York: Harper Collins, p. 107-127.

8. Dewey, J. (1916/2008) Democracy and Education. California: Wilder Publications, p. 78-97.

9. Freire, P. (2000) Pedagogy of the Oppressed. New York: Continuum, p. 71-86.

10. Giroux, H. (1988) Teachers as Intellectuals. Towards a Critical Pedagogy of Learning. Massachusetts: Bergin \& Garvey Publishers, p. 121-142.

11. Gottfried, A. E., Fleming, J. S., Gottfried, A. W. (2001) Continuity of Academic Intrinsic Motivation from Childhood through Late Adolescent: A Longitudinal Study. Journal of Educational Psychology, No 93, p. 3-13.

12. Heidegger, M. (1964) Being and Time. London: Harper \& Row Publishers, p. 21-35.

13. Heidegger, M. (1995) Taideteoksen alkuperä [The Origin of the Work of Art]. Helsinki: Taide, p. 1-103 (in Finnish).

14. Hesse, H. (1972) Lasihelmipeli [Glass Pearl Game]. Helsinki: Kirjayhtymä, p. 540 (in Finnish).

15. Hollo, J. A. (1959) Kasvatuksen maailma [The World of Education]. Porvoo-Helsinki: WSOY, p. 51131 (in Finnish).

16. Jankélévitch, V. (2003) Music and the Ineffable. Princeton \& Oxford: Princeton University Press, 176 p.

17. Kaila, E. (1954) Syvähenkinen elämä [The Profound Life]. Helsinki: Otava, p. 87-119 (in Finnish). 
18. Kannas, L., Välimaa, R., Liinamo, A., Tynjälä, J. (1995) Oppilaiden kokemuksia kouluviihtyvyydestä ja kuormittuneisuudesta sekä koulukiusaamisesta Euroopassa ja Kanadassa [Pupils Experiences of Bullying and School Enjoyment In Europe and In Canada]. In: Teoksessa L. Kannas (Eds.) Koululaisen kokema terveys, hyvinvointi ja kouluviihtyvyys [Pupil's Experiences on Health, Wellbeing and School Enjoyment]. Helsinki: Opetushallitus, p. 131-149 (in Finnish).

19. Lång, M. (2005) Psykoanalyysi ja sen soveltaminen musiikintutkimukseen [Psycho Analyses and its Applications in Music Research]. Doctoral thesis. Studia Musicologica Helsinkiensis 1, p. 3-92 (in Finnish).

20. Lehtonen, K. (1986) Musiikki psyykkisen työskentelyn edistäjänä [Music as a Promoter of Psychic Work]. Doctoral Thesis. Turun yliopiston julkaisuja - Annales Universitatis Turkuensis, p. 56, 91-122 (in Finnish).

21. Lehtonen, K. (1988) Musiikin ja psykoterapian suhteesta [On the Relation of Music and Psychotherapy]. Psykiatrien tutkimussäätiön raportteja 79, Helsinki, p. 45-56 (in Finnish).

22. Lehtonen, K. (1993) Musiikki sitomisen välineenä [Music as a Means of Binding]. Reports of Psychiatria Fennica, No 109. Helsinki: Psykiatrian tutkimussäätiö, p. 2-20 (in Finnish).

23. Lehtonen, K. (1996) Musiikki, kieli ja kommunikaatio. Mietteitä musiikista ja musiikkiterapiasta. Jyväskylän yliopiston musiikkitieteen laitoksen julkaisusarja [Music, Language and Communication. Thoughts about Music and Music Therapy]. In: Tutkielmia ja raportteja, No 17, p. 3-32 (in Finnish).

24. Lehtonen, K. (2007) Musiikin symboliset ulottuvuudet [The Symbolic Dimensions of Music]. Jyväskylä: Suomen musiikkiterapiayhdistys r. y., p. 52-69 (in Finnish).

25. Lehtonen, K. (2009) Musiikki luovana tilana [Music as a Creative State]. (Unpublished manuscript), 15 p. (in Finnish).

26. Leichter, K. (1984) Musiikki taidemuotona [Music as an Art Form]. Synteesi 1-2, p. $42-43$ (in Finnish).

27. Mansnerus, I. (1992) Epätoivosta syntyy valoisa sinfonia [A Light Symphony Rises from Despair]. Classica 1, p. 8-9 (in Finnish).

28. Mansnerus, I. (1993) Emootio on voima ja kahle [Emotion is Both Strength and Chain]. Classica 1, p. 14-15 (in Finnish).

29. McClary, S. (1985) Afterword: The Politics of Science and Sound. In: Jaques Attali (1985) Noise: the Political Economy of Music. Minneapolis \& London: University of Minnesota Press, p. 149-158.

30. Nonaka, I., Takeuchi, H. (1995) The Knowledge Creating Company. Oxford: Oxford University Press, $284 \mathrm{p}$.

31. OPS (2004) Perusopetuksen opetussuunnitelman perusteet. http://www.oph.fi/ops/perusopetus/pops web.pdf (08.04.2008.) (in Finnish).

32. Paavola, S. (2006) On the Origin of Ideas. An Abductivist Approach to Discovery. Doctoral thesis. Helsinki: University of Helsinki, p. 32-62.

33. Rantala, V. (1986) Semioottinen teko [Semiotic Achievement]. Synteesi 5, 4, p. 26-30.

34. Rechardt, E. (1984) Musiikillinen ajattelu, ruumiilliset merkitysskeemat ja symbolinen prosessi [Musical Thinking, Bodily Syntax Schemes and Symbolical Process]. Synteesi 3, p. 83-94 (in Finnish).

35. Regelski, T. (1996) Prolegomenon to a Praxial Philosophy of Music and Music Education. Finnish Journal of Music Education 1, p. 24-38.

36. Salmela-Aro, K., Nurmi, J.-E., Kiuru, N. (2007) Nuori valintojen edessä - tutkimus [Young Person in Front of Choices - Research]. http://www.jyu.fi/ytk/laitokset/psykologia/Tutkimus/finedu/finnedu tulokset_2007 (08.04.2008.) (in Finnish). 
37. Stern, D. (1995) The Interpersonal World of the Infant: A View from Psychoanalysis and Developmental Psychology. New York: Basic Books, p. 37-138.

38. Tarasti, E. (2003) Musiikin todellisuudet. Säveltaiteen ensyklopedia [The Realities of Music: the Encyclopaedia of Music as Art]. Helsinki: Yliopistopaino, p. 205-209 (in Finnish).

39. Torvinen, J. (2007) Musiikki ahdistuksen taitona. Filosofinen tutkimus musiikin eksistentiaalisontologisesta merkityksestä [Music as an Ability for Anxiety]. Suomen Musiikkitieteellinen Seura - Acta Musicologica Fennica 26. Helsinki, p. 113-117 (in Finnish).

40. Välimäki, S. (2005) Subject Strategies in Music-A Psychoanalytical Approach to Musical Signification. Acta Semiotica Fennica XXII. Helsinki \& Imatra: Finnish Society for Semiotics \& International Semiotics Institute, p. 40-44.

41. Willis, P. (1978) Profane Culture. London: Routledge \& Kegan Paul, 212 p.

42. Winnicott, D. W. (1966) The Location of the Cultural Experience. International Journal of Psychoanalysis 48, p. 369-372.

43. Winnicott, D. W. (1971) Playing and Reality. Harmondsworth: Penquin Books, p. 1-25.

44. Winnicott, D. W. (1959/1982) Theory of Parent-Infant Relationship. In: Sutherland, J. D. (Eds.) The Maturational Processes and the Facilitating Environment. London: Hogarth Press, p. 37-55.

45. Wittgenstein, L. (2001) Tractatus Logico-Philosophicus. London: Routledge \& Kegan Paul, p. 3-91.

Professor of Education Kimmo Lehtonen

$\mathrm{PhD}$ (Education) Docent of music therapy

University of Turku, Department of Education

Address: Assistentinkatu 5, Fi-20014 University of Turku, Finland

Phone: +358 405391407

E-mail:kimleh@utu.fi

Adjunct professor in art and music education Antti Juvonen

$\mathrm{PhD}$ (Music education), Senior lecturer

University of Joensuu, Department of Applied Education

Address: P.O. Box 11180101 Joensuu, Finland

Phone: +358405830544

E-mail: antti.juvonen@joensuu.fi 